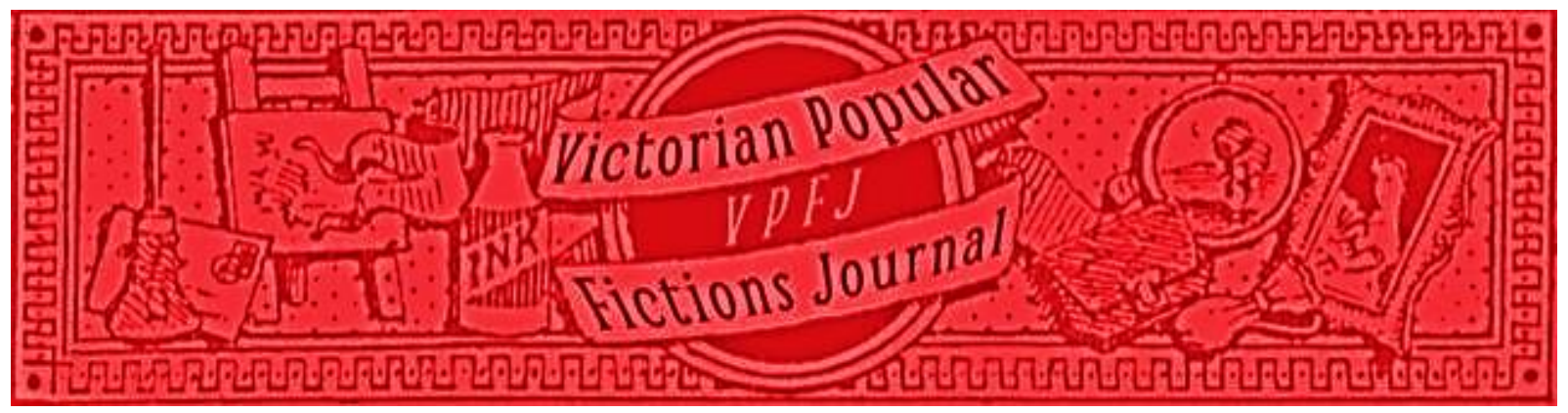

\title{
Young Aspiring Women Writers, Romantic Love and Disillusionment in Rhoda Broughton's A Beginner (1894) and A Fool in her Folly (1920)
}

\section{Graziella Stringos}

\begin{abstract}
Despite significant writing by women in the seventeenth and eighteenth centuries, it was in the nineteenth that fiction by women became extensive and widely published, prompting numerous - sometimes prejudiced - evaluations of their works. The popular writer Rhoda Broughton (1840-1920), herself subject to adverse and biased criticism, addresses the notion of female imagination and creativity and the Victorian conception of the female writer in her two novels, A Beginner (1894) and the posthumous A Fool in her Folly (1920). Broughton relates the arduous journey of young first-time writers, Emma Jocelyn and Charlotte Hankey respectively, and exposes the limited opportunities open to them in both the private and public spheres. Two novels focus on the two young heroines - women, lovers and writers - in such a way that initiation becomes a major site for the exploration of female consciousness and experience. The convergence of the fictive and the real in the two texts also serves to highlight the relevance of literature by women. This is achieved firstly through the juxtaposition of the two heroines' vicissitudes with those of real women, including Broughton herself; secondly, through the heroines' admiration for other women writers, particularly Charlotte and Emily Brontë and George Eliot; and thirdly, in the echoes of texts by women writers including Jane Austen and Anne Brontë. Contemporary society's prejudice against unconventional women is confirmed but clearly not endorsed in the endings of the two texts. Broughton's thought-provoking studies of women's quests for personal and professional identity classify her as a perceptive writer who advocates the intellectual and emotional empowerment of women at a time when women were challenging limited definitions of their sex and fighting for their social rights.
\end{abstract}

\section{Key Words}

Rhoda Broughton; feminism; women's writing; Victorian literary milieu; female emancipation; private and public spheres; sensation fiction; popular fiction; love/romance, marriage.

Date of Acceptance: 9 July 2020

Date of Publication: 13 July 2020

Double Blind Peer Reviewed

\section{Recommended Citation}

Stringos, Graziella. 2020. "Young Aspiring Women Writers, Romantic Love and Disillusionment in Rhoda Broughton's A Beginner (1894) and A Fool in her Folly (1920)." Victorian Popular Fictions, 2.1: 24-42. DOI: https://doi.org/10.46911/MASW8983 


\title{
Young Aspiring Women Writers, Romantic Love and Disillusionment in Rhoda Broughton's $A$ Beginner (1894) and $A$ Fool in her Folly (1920)
}

\author{
Graziella Stringos
}

\section{Introduction}

In her famous 1929 essay "A Room of One's Own," Virginia Woolf insisted that "a woman must have money and a room of her own if she is to write fiction" ([1929] 2007: 565). She also stressed the limitedness of women's education and described the hostile environment in which women's entrepreneurial creative intelligence is met in society. "Women and fiction," she claimed, is "a subject that raises all sorts of prejudices and passions" (566) even in her own time. These observations came almost thirty years after the end of the nineteenth century which had seen an unprecedented surge in women's writing. Women were substantial producers of Victorian fiction: they dominated the circulating libraries and were the major source of sales for the classic three-decker. "This, which is the age of so many things - of enlightenment, of science, of progress - is quite distinctly the age of female novelists," wrote Margaret Oliphant in 1855 (555). Victorian women who were interested in a writing career, "beginners" as well as more established writers, had to cope with and overcome various barriers. Firstly, women's financial security depended on the men in their life - fathers, brothers and, finally, husbands and access to their money, if they inherited any, was often complicated. ${ }^{1}$ Secondly, irrespective of class, they were often debarred from proper education or supplied with an insufficient scope of knowledge prescribed for women (Burstyn ([1980] 2017). Thirdly, they generally struggled to find an adequate working space in their own houses, with married women often having to juggle domestic duties and work demands. Finally, before, during and after the writing of their work, women writers frequently met with disapproval and chastisement. They were often subject to harsh criticism, not only by male critics but also by fellow female novelists, critics and publishers' readers, including George Eliot, Geraldine Jewsbury and Oliphant herself. ${ }^{2}$ Inevitably, a central question in Victorian novels by women about aspiring female novelists is whether a woman writer can really find her space within the literary culture and market, a structure supported mainly by male values, financed by men and ruled by them. In this light, Woolf's "room" or, more precisely, the lack of one, becomes the definitive metaphor for all the

${ }^{1}$ The Married Women's Property Act in 1882 finally allowed women to own and control their own property. For studies on Victorian women and property in the novel, see: Deborah Wynne's Women and Personal Property in the Victorian Novel (2016) that focuses on fiction by Charles Dickens, George Eliot and Henry James; and Tim Dolin's Mistress of the House: Women and Property in the Victorian Novel (2016) for the discussion of Shirley, Villette, Cranford, The Moonstone, Diana of the Crossways and Thomas Hardy's "uncovered women." Both texts refer to contemporary social, legal and political non-fiction.

2 There has been a considerable amount of work on nineteenth-century women's misogyny since Thompson 1999. 
obstacles in a woman writer's exhausting battle for literary recognition. Unarguably, finding a room of one's own is only the beginning of the crusade. Rhoda Broughton (1840-1920) was fortunate in having not only a room of her own but a sister, Mrs Eleanor Newcome, who ensured its regulation: "Visitors to the Oxford and Richmond houses may have regarded Rhoda Broughton as the dominant figure, but Eleanor had played an essential role in their partnership, running the household and ensuring that Rhoda had all the time and peace necessary for her work" (Wood 1993: 84).

Despite the profusion of women's writing and this common female experience of struggle, the representation of women novelists as central characters in Victorian fiction is relatively rare. Rhoda Broughton, in common with her peers, portrayed several male writers in her fiction, namely the young poets Francis Chaloner in Second Thoughts (1880) and Freddy Ducane in Doctor Cupid (1886), the established novelist Ned Bromley in Concerning a Vow (1914) and the aspiring writer Willy Steele in A Thorn in the Flesh (1916). Although they encounter obstacles in their careers, their paths to success do not comprise the hostility endured by the two young aspiring women writer heroines of Broughton's A Beginner and A Fool in her Folly. Already in Broughton's first published novel, Cometh Up as a Flower (1867), nineteenyear-old Nell Le Strange considers writing a novel to earn money to save her now impoverished family from destitution, albeit a task she never embarks on. Decades later, the young protagonists of A Beginner (1894) and the posthumous A Fool in her Folly (1920) manage to do so. The two novels make use of metafiction and cleverly combine sensation elements with the New Woman novel genre. Ann Heilmann argues that "[1]ate Victorian feminist writers anticipate Virginia Woolf by several decades when they link their protagonists' quest for independence and artistic development to the notion of private living and working space: a room of one's own" ([1995] 2006: Abstract) and A Beginner and A Fool in her Folly are strongly concerned with those and related issues as they probe into various aspects of a woman's life in the nineteenth century.

As is characteristic of Broughton's novels, the two texts revolve around young women, fledglings who still need to mature as a result of what life will throw at them. The orphanprotagonist of A Beginner, Emma Jocelyn, is in her early twenties and lives with her adoptive aunt, Mrs Chantry, while, in A Fool in her Folly, the twenty-year-old Charlotte ("Char") Hankey lives a sheltered life with her two doting parents and her siblings. The two protagonists are avid consumers of literature, although Emma's repertoire seems to be vaster and more diverse. Despite the fact that they have never experienced love themselves, they secretly embark on the ambitious mission to write a novel on what they consider the ultimate subject since they are both dissatisfied with its treatment in literature. Broughton's two novels, however, do not only follow the tough journey of these first-time writers but also their first encounter with love. Each novel contains two complementary plots: a love story and a plot related to female creativity and production. In A Fool in her Folly the two plots are clearly highly dependent on each other, and, although Pamela K. Gilbert argues that the romantic plot in A Beginner is subordinate to the one of Emma's writing (2005: 137), even here the two plots feed each other and work together to initiate a debate on the restrictions in a woman's life, both affectively and professionally, as they attempt to marry the private and the public spheres.

Intriguingly, these thought-provoking studies of woman as woman, writer and lover/wife are rendered in two different modes of narration, therefore enabling the reader to view a similar female experience from two diverse standpoints. A Beginner is written in the diegetic mode of 
narration but a considerable amount of the focalisation is internal - a typical mixture of Broughton's écriture. Conversely, A Fool in her Folly is a retrospective auto-diegetic narration, with the eighty-year-old protagonist looking back on her youth's folly. In both cases, great attention is given to female consciousness as the heroine's experience is revealed through the constant reproduction of her intimate feelings and thoughts.

Indubitably, the novels are highly relevant to studies on women's writing, especially sensation and New Woman fiction produced by Victorian popular women. The convergence of the fictive and the real in the two texts serves to highlight the relevance of literature by women: this is achieved first through the clever juxtaposition of the two heroines' vicissitudes with those of real women, including Broughton herself; secondly, through the heroines' admiration for other women writers, particularly Charlotte and Emily Brontë and George Eliot; and thirdly, in the echoes of other texts by other women writers including Jane Austen and Anne Brontë. Moreover, the two novels touch upon the alleged harmful influence of romantic and sensation fiction on female readers, and, in turn, woman's production of such fiction - two highly debated subjects at the time. Finally, they are useful sites for the discussion of other important aspects of Victorian womanhood, including woman's positive influence on erring men, female emotional and sexual awakening as a result of woman's first experience of love, and marriage. In A Beginner and A Fool in her Folly, the reader is therefore engaged in a powerful debate on woman's nature and role in society, and it is clear that the fate of the two protagonists is a direct result of their social and historical reality.

New Women novelists of both sexes addressed a number of polemical issues, including the marriage question, maternity, education and professions for women, and eventually suffrage. Broughton is no exception, though her attitudes to the New Woman are often sceptical. Broughton's experiments with the New Woman genre include Scylla and Charybdis (1895) and Dear Faustina (1897). The first introduces Honor Lisle, a likeable character who exhibits some New Woman qualities, while the second concerns Faustina Bateson, an exploitative and manipulative woman who hides behind her work for 'the cause' to advance herself (Heger 2007). In the two texts under discussion, Broughton seems to be mostly concerned with the potential New Woman's attitude towards female sexuality, education, profession and marriage. In A Beginner, the other 'useful' vocation of the minor character Miss Grimston, besides "tomahawking" (Broughton [1894] 1899: 142) other people's books, is her philanthropic mission as a member of a "Delegation from the World's Women Federation for the Regeneration of Man" (153). The heroine Emma Jocelyn is in some respects a New Woman too. While she is not against marriage, she persistently avoids possible proposals and declines them when she cannot avoid them. She is much more interested in gaining knowledge and in pursuing a writing career than in matrimony and motherhood: Emma would rather choose "creativity" over "procreativity" (Ardis 1990: 21). However, if she is ready to temporarily do away with respectability for a friendship of minds, she may also be convinced to accept a marriage of minds, ideally a union of intellectual equals. A Fool in her Folly presents trickier classification problems vis-à-vis its New Woman status, especially when one takes into consideration the possibility that Broughton could have written it years before its publication and kept it secret, presumably due to its autobiographical resonances. ${ }^{3}$ Char Hankey is

\footnotetext{
${ }^{3}$ This theory may hold true not only due to the fact that, as Michael Sadleir notes, towards the end of her life Broughton used to dictate her work to her maid Pullen and the manuscript of this novel is in the author's own hand (1940: 604), but also because Broughton abandoned the auto-diegetic mode of
} 
unconventional in her need to write a novel about passionate love - an act of insubordination against accepted and established familial and social norms - but she is very similar to Broughton's earlier heroines in her impetuosity, passion and rebelliousness, and is still very much interested in love and marriage. The two novels are undeniably powerful studies of two separate quests for individual artistic expression, and, if self-awareness and the first intimation of love are part of the journey, then the plot becomes more intriguing and, in Broughton's hands, decidedly sensational.

\section{Ambition and Desire: Char Hankey's Life-changing Discoveries in A Fool in her Folly}

Specific to A Fool in her Folly is the notion of woman's alleged positive influence on degenerate men, particularly lovers, fiancés and husbands, a notion portrayed in various novels by Broughton, particularly, Not Wisely but too Well (1867) Doctor Cupid (1886) and The Devil and the Deep Sea (1910). This conviction stems directly from the Victorians' perception of woman as the angel in the house. Both fiction and non-fiction of the nineteenth century evidence this diffused belief in the transforming power of a woman's love - often referred to as "positive," "tender" and "ennobling" passion. The literature of the time abounds in such stories, and the number of wellintentioned and naïve young women ready to undertake the mission of reformation and, hopefully, salvation of their fallen lover is considerable. The female mentor-lover, a virgin and clearly untainted by any bodily desires and experience, becomes the active agent, and her pure love the presupposed tool for a man's redemption. Based on a middle-class ideal of womanhood, women were expected to be innocent and pure, men's moral superiors. Related to these, I propose two sets of female reformers that may be elicited from nineteenth-century literature: first, there is the conscious romantic female reformer, often tainted with an element of arrogance and stubbornness along with a good dose of naivety and goodwill; second, there is the woman who initiates her lover's journey of salvation unconsciously through a steadfast moral attitude and exemplary behaviour. Like Anne Brontë's Helen Huntingdon, in The Tenant of Wildfell Hall, who believes that she can save the degenerate Arthur Huntingdon ("There is a secret something - an inward instinct that assures me I am right. There is an essential goodness in him - and what delight to unfold it! [...] that Heaven has designed me for this!" (Anne Brontë [1848] 1996: 152-3)), Char Hankey belongs to the first group. Char enthusiastically claims that:

I had been chosen to be the "good and pure woman" whose chastening and elevating influence had been lacking in his downward career. I had been the solitary specimen of my class who had had the courage to embark on the high emprise.

Broughton [1920] n.d.: 232)

Patricia Menon concludes that, irrespective of gender, the figure of the mentor-lover in Victorian fiction gives space for "explorations of a wide range of interconnected issues stemming from the relationship of love to morality, power and judgment. Among the subjects brought into focus in this way are sexuality, family, selfhood, freedom, conduct, and the nature of male and female roles" (2003: 1). In fact, in the richly textured A Fool in her Folly, the notion of woman's

narration, the mode typical of her early writing, after her fifth novel. The diegetic mode became her first preference and she never resorted to it again in her longer fiction except in A Fool in her Folly. 
positive influence is intricately interwoven with other topical concerns, specifically female sexual awakening, marriage and woman's writing.

Char's imperative desire is "[t]o write! To be perhaps a second Charlotte Brontë!" (Broughton [1920] n.d.: 11): her ambition is to write a novel in which she reveals the power of love, "the greatest thing in the world, the greatest influence for good" (180). However, significantly, she lacks first-hand experience and real-life models. Her sister and her future husband fail to provide her with them; for instance, when their future house develops plumbing problems, Char sarcastically notes that "[i]t was prosaic that love's course should be blocked by a plumber; but that idea had occurred to none of us but me" (13). Char conceives of true love as something powerful, rapturous and overpowering, and deems her sister's relationship "a mere parody of the real thing" (31). At a country dinner she confesses to a complete stranger her "ardent struggle to find out how men felt, acted, and looked when under the domination of the passion par excellence" (59). Although readers might smile at the heroine's innocent attempts to gain knowledge about men and love, they can already anticipate her humiliating downfall, mainly through her boldness and sense of superiority.

Char has no choice but to rely on reading for inspiration and role-models. Her imagination has been stimulated by the works of supposedly unsuitable British and French romantic stories, including Manon Lescaut, La Nouvelle Héloïse, Jane Eyre and Guy Livingstone. ${ }^{4}$ A "believer in the tradition," Char "had seen simple Miss Eyre tame Mr. Rochester and believed she was capable of the same success" (Silberg 1977: 161). She admired Jane's influence on Rochester and "so overwhelming, so scorching a passion as that with which Jane inspired him" (Broughton [1920] n.d.: 61). Not incidentally, her favourite poets are Byron, Shelley and Tennyson. Of the former she writes: "How I scorched my virginal soul at his furnace fires!" (20). The repetition of fire imagery in the two excerpts and the direct reference to virginity are evidently symbolic and proleptic. Like, for instance, Mary Elizabeth Braddon in The Doctor's Wife, Broughton warns against the dangers of reading too many novels and leading a sheltered and dull existence: for the imaginative and restless young woman this combination is often catastrophic. Like Braddon's heroine, the dreamy Isabel Sleaford, Char makes these works the standard by which to judge love and life.

Char covertly writes the first draft of her novel, Love - "a compilation of all-second hand emotions she has secretly absorbed" (Wood 1993: 117), full of preconceived notions acquired from books. She is dissatisfied with her work so she decides to destroy the manuscript. It is, however, discovered before she manages to do so. Her family disapproves, and as a punishment she is sent to her Aunt Florinda in another small village. Unintentionally, her parents have sent her to the place where she will meet William (Bill) Drinkwater, the incarnation of passion and

${ }^{19}$ Manon Lescaut (1731) is a novel by French novelist Abbé Antoine-Françoise Prévost, which narrates the story of a mutually destructive passion between a refined but weak nobleman and a bewitching demimonde. Guy Livingstone (1857) is an influential novel by George A. Lawrence, in which immorality and force were glorified; its eponymous hero was a blackguard - immoral, aggressive and vengeful. $L a$ Nouvelle Héloïse (1761), by the French writer Jean Jacques Rousseau, was inspired by the true, tragic and passionate love story between the medieval theologian Abelard and his seventeen-year-old pupil, Héloïse. The story includes seduction, pregnancy, secret marriage, castration and forced parting. The Rousseau made the most impression on Char and reflects her plans. Menon (2003) describes La Nouvelle Héloïse as very influential in spreading the convention of the mentor-lover and so we can see Broughton following convention here to highlight the theme. 
the embodiment of the fascinating anti-heroes and Byronic heroes of her preferred fiction: it is now that the second-hand affair becomes a first-hand experience. Char learns about Drinkwater's bad reputation but she slowly falls in love with the handsome profligate, or, more appropriately, in love with the idea of romance, and, a firm believer in its redeeming quality, she, his "pure woman" (Broughton [1920] n.d.: 255), decides it is her mission to save him. She takes this vocation, "the great, the holy task" (326), very seriously and Drinkwater encourages her to do so.

At her aunt's house, Char resumes writing; the novel is again Love, but she writes with more vigour and verisimilitude, retaining the passionate lovers of the original story, Fulke and Eleonora, who are now full of life and credibility. Meaningfully, in her secret affair with Drinkwater, "she is both pursuing experience for her writing and providing herself with a romantic role to play within the relationship" (Silberg 1977: 160) - that of lover-reformer. Her two most significant aspirations are closely linked: as her novel-writing and passionate affair with Drinkwater merge into one experience, Fulke and Eleonora naturally become incarnations of herself and Drinkwater. Char envisages a double success and her daydreams are full of triumph in both fiction and love. These triumphs she presumptuously plans to eventually lay at her parents' feet:

I could look forward to the time when I should advance to my parents with Mr. Drinkwater, figuratively, in one hand and LOVE (which by that date would have attained a phenomenal anonymous success) in the other, and say, "This is the husband I have chosen, and whom I have been able to restore to his true and Higher self, and this is the book which I - which we all - owe to him.

(Broughton [1920] n.d.: 232-3)

Michael Sadleir compares the young Char to the "outspoken warm-hearted maidens" of the earlier books "who had so often loved and languished" (1926: 549). In this "tale of capricious fancy and blighted passion," Broughton views her heroine with "the right understanding and the right irony" (Sadleir 1926: 549): the voice narrating the story, that of the now eighty-year-old Char looking back with wisdom, insight and a curious mixture of pain and humour, shapes the reader's sympathy towards the heroine - not without recognition of the young heroine's artlessness - and also predicts her ultimate failure. The reader and the older Char are aware of Drinkwater's manipulation: he keeps things from Char and confesses what is convenient, therefore, keeping her in his power with his assumed attitude of repentance and honesty. For instance, he tells her that he liked Charlotte Yonge's The Heir of Redclyffe (1853), a novel in which the temperamental but kind hero, Guy Morville, learns the virtues of patience and selfcontrol through contact with the women of the Edmonstone family.

Broughton also plays with the concept of the pure and virginal model and makes Char capable of strong desire and engulfing passion. Char discovers simultaneously the power and fragility of human nature, and becomes aware of her own limits. Char feels she is being dragged down and is sinking lower with Drinkwater instead of helping him towards his higher emotions:

As time went on, I could not disguise from myself the fact that I had not only his but my own passion to fight against. [...] Absolutely no man had ever made the smallest attempt at lovemaking towards me, and my text books had given me no safe clue as to how much rope could be entrusted to a lover without the danger being incurred of his hanging himself or me.

(Broughton [1920] n.d.: 228) 
Concerned and confused she asks: "Was this the road of purification and elevation on which I had set forth with so clean and high a purpose? What if, instead of my raising him, he were to drag me down into a pit of sensuality?" (233). Char is incapable of seeing through the charming, affected and enticing words of a seducer like Drinkwater, and her combination of "odd innocence" and "uncanny and unseemly book knowledge" (228) fails to help her understand, interpret and control her emotions. Inevitably, as they kiss and exchange "torrid endearments" (293) in a secluded shanty she falls victim to his sexual appeal. She experiences for the first time that "phenomenon" so familiar "on the printed page, but never before in the flesh." (229) She is finally living an actual romance.

\section{Deliberation and Confusion: Emma Jocelyn's Two Questionable Flames in A Beginner}

Compared to A Fool in her Folly, love in A Beginner is neither passionate nor remarkable. The sensational representation of romantic love in the novel is limited to the fictive thwarted lovers, Odo and Elfrida, in the heroine's own novel, Miching Mallecho. There are two potential love interests for the heroine: the young writer and critic, Edgar Hatcheson, and the vieux papa, $\mathrm{Mr}$ George Greville, to whom Emma has been promised in marriage since she was a young girl. Edgar dominates the first half of the book and is established as the prospective suitor, despite his social class and his prejudice against women writers. Greville, most probably a useful afterthought on Broughton's part, is then introduced. Always caring and attentive to Emma's happiness, Greville assumes the roles of father and mentor-lover simultaneously: he gives her sound advice and a chiding when she needs it, such as when he tries to open her eyes to her adulation of Edgar. In both relationships, however, physical desire is lacking and Emma clearly does not experience awakening. The closest she comes to romantic sentiment is when, after a squabble related to Edgar, "[f]or the first time in her life the prospect of meeting 'old George' is quickening the beat of Emma's healthy heart. [...] It is useless - to herself, at least - to deny that she has missed him a good deal" (Broughton [1894] 1899: 322). In another scene, the emphasis is on their being perfectly and happily at one. When juxtaposed with the ardent emotions of other awakened heroines, like Broughton's Char, Kate Chester, Nell le Strange, Lenore Herrick, Lavinia Carew and, the reader assumes, the fictive Elfrida, these sensations are extremely mild.

Equally, Edgar does not stimulate Emma's emotions but her intellect: "“A friendship built upon books [...] is naturally hungrier than any other, and there is not much fear [...] of ours lacking food"' (353), she tells Edgar. She enjoys having scholarly conversations with him, spends hours with him in Lord Heathcote's library (turning up late for meals), and flatters him with compliments on his knowledge and literary prowess. Emma justifies this clearly unconventional behavior since it is done in the company of "an Intelligence" (95). Emma's idolisation of Edgar is due to his published critical essays which she admires, including "Warp and Woof". The reader may smile but, as in Char's case, is also aware of imminent disillusionment. Edgar's constant embarrassment and "almost oppressive gratification" (69) at the eulogies she places on "his paltry altar" (69) and his "continually raising her from the knees" (92), along with his silent admission that he is "not so great a man as she takes him to be" (147) further sustain this supposition. Although she puts Edgar on a pedestal, her feelings for him are unclear even to herself, as revealed during moments of introspection: 
Miss Jocelyn has never been in love, and for a person who has depicted with such sultry force the amatory emotions of her Odo and Elfrida, has curiously little acquaintance with the tender passion. She is conscious that she neither behaves nor feels quite like Elfrida; but then, for the development of her moral purpose, she had been obliged in Elfrida's case to describe the very drunkenness of passion. Can one be in love and not drunk? She loves his conversation; she loves his writings; she loves his high character; but does she love him?

(Broughton [1894] 1899: 365)

Edgar represents to Emma what Philip Wakem meant to Maggie Tulliver in George Eliot's The Mill on the Floss: like Maggie, Emma is thirsty for knowledge and Edgar could quench this yearning. The similarity ends there, however, for Edgar is young, healthy and attractive while Philip's physical deformity make him sexually undesirable to Maggie. Edgar's malformation is his social class, an opinion shared by Emma's social equals, Mrs Chantry, Tom Heathcote and Greville. Emma unwaveringly defends this intellectual friendship "between teacher and taught" (281), and ignores her aunt's and Greville's reservations. Emma values independence and intellectual improvement highly, and aspires for a fulfilling and useful profession, ideals promoted in Broughton's Belinda (1883) and Eliot's Middlemarch (1872). She shuns love relationships that will inevitably lead to marriage and, consequently, to lack of personal and creative space. Most certainly, the reason behind Emma's rejection of Tom Heathcote's offer of marriage a few years earlier is related to this preference. He is now married to her cousin Lesbia. Her fleeting consideration of Edgar as a possible suitor, in fact, may only be explained in terms of her hope of a marriage of minds: "Does not the thought of walking side by side in noble unity of purpose along the lofty path of intellectual endeavour, helping and helped, present itself to her as the worthiest ideal ever likely to be set before her?" (364). As she contemplates this scenario, she becomes aware of the mutual advantages of such an alliance but remains undecided.

\section{The Ultimate Vocation: Women's Writing about Love and its Reception}

To refer back to Woolf's essay, both Emma and Char manage to find the space and the time to pursue their dream: their comfortable social background, their youth and freedom from marital ties and duties make this easier. Char admits that she is "blessed with a little sanctuary of my own, into which I had of late discouraged intrusion as much as I could" (Broughton [1920] n. d.: 41), and a well-supplied home library. She writes in the early and late hours of the day to avoid detection, and her parents do not expect her to read books that are considered harmful (which she does nonetheless). The first pages of Love, however, are momentously written on the table of a newly "redone boudoir" (17), a private sitting room, with a new quill pen when Char decides to miss church, thereby gaining two hours of solitude and peace. Later, when Char is banished to Aunt Florinda's house, away from her family's scrutiny, she is free to resume her writing. Similarly, Emma has "a room of her own" - a turret - where she can escape to read and write, although her aunt frequently visits her unannounced. Emma, who is jealous of men's apparent unlimited access to knowledge, is also allowed to visit the extensive "historic library" (Broughton [1894] 1899: 186) of old Lord Heathcote, her kindly neighbour, and read from the vast range of books. One of the major ironies in A Beginner is that Emma has a room of her own while Edgar, a professional critic for the Epoch, has to work in the dining room disturbed by his brothers and sisters. The eldest of five bitterly confesses to her: " $\mathrm{Oh}$, if I had but a room of my own! You do not know what it is, this perpetual din of interruption!'” (p. 351). Emma guiltily 
thinks of how easy it was to write her novel in the comfort of her turret. Renowned for her wit and satirical bent in both her life and her writing, Broughton could not resist including a twist on a conventional situation. However, she was realistic enough about the fate of Emma's work after its publication: while Emma's Miching Mallecho struggled, Edgar's productions thrived. The problem, Broughton is arguing, goes beyond the luxury of a room of one's own to the gender hierarchy of the publishing industry at large.

The two heroines' mission to write a novel about love underlines their shared belief that passion is often not truthfully portrayed in fiction. "I wished to draw as vigorous a picture as lay in my power of what has been the greatest motive force of human action from the beginning of time" " (80) is Emma's explanation to her shocked and incredulous aunt, Mrs Chantry, while Char explains that:

I wanted to show how illimitable its power is as a lifter up and restorer - how, when it is real and intense, as I hoped to draw it, it is able to raise a man or woman out of the lowest sloughs of degradation and - and debauchery into which he or she may have fallen!

(Broughton [1920] n.d.: 180)

Emma's intentions are to illustrate, expose and edify, while Char wants to celebrate love and its benign influence. Inspired by the work of admired women writers, particularly the Brontës and George Eliot, both revered by Broughton herself, the two heroines set out to transform the presumed uninteresting reality of courtship and love and make it extraordinary. The novels are essentially a fabrication of their imagination and a rereading, reinterpretation and rewriting of familiar plots. There is clearly an element of presumption and arrogance on the part of the two aspiring writers: Emma's predicament is treated with humour and an endearing tone while the older and wiser Char looks back chidingly on the foolish version of herself. Emma's novel has already been completed and printed when the novel opens so there is no information about her creative process. The reader eventually learns, however, that, despite her social advantage, she had to borrow money from an unsuspecting Tom Heathcote to be able to cover the publishing expenses - which takes us back once more to Woolf's list of imperatives. In contrast Char's two attempts at writing a magnum opus are closely followed and prove to be an experience filled with conflicting emotions, elation and despair, pride and dissatisfaction. Char destroys both manuscripts, and her novel is never published. Although there are no passages reproduced from either of the women's novels (the closest the reader gets are a few tantalising quotations from established poets as mottos for Char's chapters and some details about the protagonists of Love in A Fool in her Folly), the reader can infer their sensational content. Emma's love story between Odo and the married Elfrida -"a minx"” in Mrs Chantry's words (Broughton [1894] 1899: 132) - revolves around the sensational themes of adultery and heredity which Broughton exploited in other novels, especially Scylla and Charybdis, Cometh Up as a Flower, Belinda and Between Two Stools (1912). Char's story of Eleonora, who is perpetually living in a "burning fiery furnace" (Broughton [1920] n. d.: 34) as she tries to raise her beloved but degenerate Fulke from the "abyss" (224), is implicitly presented as autobiographical, reflecting Char's relationship with Drinkwater. Yet, despite Emma's and Char's insistence on exposing the extraordinary realities of love, the reader is deprived of the young writers' actual representation of this, thereby underscoring the reticence about female sexuality and sexual experience enforced during the period. 
In this, both A Beginner and A Fool in her Folly continue the debate about literature by women in the literary market, its relation to age and to passionate love. The efforts of both heroines are disparaged by family and friends, and, in Emma's case, by critics too. Relationships - familial, friendly and amorous - are strengthened, threatened or destroyed according to their reactions to the novel and to Emma and Char as female authors writing about passion. Char's shocked parents punish her by exiling her temporarily from home until she repents, while Emma's relatives and friends modify their perception of her: she changes from prudish to passionate for Lesbia Heathcote, from intelligent to naïve for Tom Heathcote, and, for Mrs Chantry, from daughter to stranger. Both heroines are negatively redefined by their writing. When faced with continuous criticism Emma asks herself:

Is it absolutely necessary for her to go on pursuing this path, thick set with thorns and sparsely strewn with roses as it has proved itself to her? Is her vocation so undoubted, in spite of the testimonies to the contrary which she has painfully and plentifully reaped?

(Broughton [1894] 1899: 345)

Confused by the pejorative criticism of her well-intentioned work, she even starts questioning her own integrity and wonders if there is "a stain of impurity unsuspected in herself" (182).

In fact, in both novels, familial and professional critics of both sexes denigrate women's novel writing. Everyone concurs that women are not meant to experience or understand passion, and, even worse, write about it: "'Good Lord! [...] and may I ask which of the passions you have made interact? The passions in a woman's mouth generally mean one! Is it the usual?", (19) Mrs Chantry asks her niece, while Edgar believes that there are "subjects that women had better let alone" (49) and that women writers are "wanting in originality" (93). Edgar's prejudiced attitude towards female authorship, discerned even by Emma but naively dismissed due to her belief in her novel's worth, has more enduring results, for he writes a scathing review of Miching Mallecho in the influential and widely read magazine Porch in which he describes the novel as "contemptible" and belonging to "the family of simple trash" (171). Significantly, it is Edgar who recognises the sex of the author while previous favourable criticism had attributed the novel to a man. This is a mistake which Emma relishes for her choice of launching the book anonymously ("by A Beginner") was meant to "disarm hostility" and mislead reviewers to take her for a man (p. 7). In his review, however, Edgar criticises the "young, female, foolish" (172) author with pretensions of "a seer" and "a teacher" (171); it is a male judgement on woman's competence that decides Miching Mallecho's fate. Emma is ignorant of who wrote the "slasher" (177), and despite tell-tale signs that Edgar had written it, she instead suspects Miss Grimston, a failed writer turned bitter who, she knows, enjoys "demolition" (211) of other people's work. Following Edgar's review, the sales of the novel plummet irreversibly.

Although Emma's and Char's experience is indeed limited, the failure of both to achieve their goals may still be greatly accredited to critical prejudice. As Elaine Showalter contends, "[t]o their contemporaries, nineteenth-century women writers were women first, artists second" and "[w]hen the Victorians thought of a woman writer, they immediately thought of the female body and its presumed afflictions and liabilities" (1999: 73, 76). "As a woman, Emma is marked primarily by gender and class. [...] Emma's text is representative of her body" (Gilbert 2005:137). For the disapprovers, Emma and Char become a symbol - a woman writer who has no business writing a novel on a subject deemed improper, reiterating Oliphant's pronouncement in her searing first review of Cometh Up: "It is a shame to women so to write; and it is a shame to the women who read and accept as a true representation of themselves and 
their ways the equivocal talk and fleshly inclinations herein attributed to them" (1867: 299). This is also clearly exemplified in the emphasis put on Emma's and Char's virginity in the two texts. Words and phrases used to describe Emma's first novel are also reflective of the girl's sexual purity and inexperience; for instance, there are references to "her maiden novel" (Broughton [1894] 1899: 8), and to the fact that her newly arrived volumes were "standing in a virginal row - for their bindings are carefully white wrappered [sic]" (6). Emma is also looked upon by Edgar, conspicuously a believer in the middle-class ideal of womanhood, as a "white nymph" (69). Therefore, the phallic image of the turret becomes essential: Emma has composed her novel in a masculine space, as it were, and there given birth to her "offspring" (98). An innocent no more, she is nonetheless still perceived and treated as a girl who needs to be protected, and silenced into obedience - in other words, domesticated.

Emma's visit to her publishers in London, Messrs Brent and Lockwood, contains another important irony. The compassionate publisher confirms her fears about the impact of the review on sales but he does not discourage her, instead telling her that "'after a second or third venture you will grow more case-hardened"” (254). He also advises her to write a domestic novel: "It is always difficult to foretell what the public will like. The only perfect safe line is the domestic" (252). He recommends reading the novel "Hame! Hame! Hame!" written on " "purely domestic lines", asserting that "the reviewers have been almost unanimous in its praise, and we can't print it fast enough"' (253). Paradoxically, after years of chastisement due to the sensational elements in her fiction, in a disparaging review of Foes-in-Law, Enoch Arnold Bennet condemns Broughton, whom he calls "the typical novelist of domesticity" (1901: 61) because, in her books, small communities, families essentially, are preoccupied with their "own trifling affairs" (66). Broughton's case illustrates the fact that, irrespective of the novel's content and approach, critics will always find fault with it. After Emma reads "Hame!" promptly sent by her publisher, she is more convinced of "the merits of her creation" (Broughton [1894] 1899: 256). She muses:

If the British public can be persuaded by its literary guides that black is white, to the extent of swallowing with avidity the unspeakable twaddle of the novel of whose popularity she had been assured, it can only be owing to the unexplained malignity of those guides that the same public has failed to recognize the high drift and original treatment of that work to which Shakespeare himself has stood godfather.

(Broughton [1894] 1899:256)

Emma might be presumptuous in her belief in her intellectual and perceptive superiority and in Shakespeare's championing of Miching Mallecho, but her observation on what the public is fed or made to believe through the structures of the publishing houses and reviewers is worth considering.

In his now infamous article on "Sensation Novels," H. L. Mansel highlights

the indications of a wide-spread corruption, of which they [sensation novels] are in part both the effect and the cause; called into existence to supply the cravings of a diseased appetite, and contributing themselves to foster the disease, and to stimulate the want which they supply.

(Mansel 1862: 481).

In suggesting that her heroines' novels were sensational then, Broughton could discuss the notion of influence and the impressionability of female consumers, the subject of a number of novels by Broughton herself, like Cometh up as a Flower, Not Wisely but too Well, Red as a Rose Is She and Mamma, and by other novelists like Braddon and Eliot, including The Doctor's 
Wife and Rosamund Vincy's plot in Middlemarch. It must also be recalled that both Emma and Char are avid readers of fiction. Ironically, the story of Odo and Elfrida in Miching Mallecho, meant to warn against excessive indulgence in passion and to advocate "the absolute need for much greater self-control, loftier principles, and a stricter discipline" (Broughton [1894] 1899: 112), has the opposite effect: not for nothing is "miching mallecho" a reference to Shakespeare's Hamlet, where it means mischief. ${ }^{5}$ This mischief's supreme manifestation can be found in the behaviour of Emma's cousin, Lesbia, a key character in terms of the wholesale consumption of literature and perhaps "a fair representative of the average public" (107); she is the one who raves about Emma's novel, which, to the young writer's dismay, she describes as " "the most delightful book I ever read, and [...] desperately improper!" and the most "'risqué story"” in English (108). While her adulterous propensities are suggested by her name taken from the scandalous married beloved of the ancient Roman poet Catullus, it is after reading the novel that Lesbia starts questioning the soundness of her marriage, neglecting her domestic duties and spending time flirting with Malcolm McDougall, who, like her, prefers the "'strong passages"” in Miching Mallecho (316). This validates the Victorians' belief in the noxious influence of fast novels, in this case, not on a young girl but on a married woman with children, which makes such influence more serious and dangerous. Evidently, the fledgling novelists have underestimated the power of the written word and of their potential readers' imagination.

Furthermore, Emma's and Char's literary debuts may be compared to Broughton's own. Geraldine Jewsbury, Bentley's editorial reader, professed herself shocked by Broughton's first novel, Not Wisely, and advised against its publication since she considered it unfit for the reading of decent people. Similarly, the criticism levelled against Emma's Miching Mallecho is for the violent depiction of passion and for its moral tone. It may even be that Miss Grimstone, who Emma suspects of having written the "slasher," may be modelled on Jewsbury. The absence of excerpts from the novel and the narrator's reticence on the literary merits of Emma's novel leave the reader jostling among interpretations of dismissal or flattery that the narrator does offer. A positive review of Miching Mallecho claims that "[f]or the headlong vigour and uncompromising reality in the love scenes we know no parallel in English fiction, except perhaps in "Wuthering Heights"' (125). Another reviewer concludes that "[b]y his masterly analysis of character, and his scientific treatment of the philosophy of life, he reminds us at every page of the method and manner of George Eliot" (124). The two reviews significantly compare aspects of the beginner's work to those in the works of established women writers; however, these appraisals are, as we have seen, quickly overshadowed by an influential negative one. Emma, too, is fully aware that her immediate critics lack "impartiality" and "competence" (345): neither acclaimers (Lesbia and McDougall) nor disclaimers (particularly, Mrs Chantry and Edgar) are reliable. The same may be said of Char's Love. Char's doting but very traditional parents condemn her occupation and also focus on the subversive nature of novel writing and its questionable content; when her father describes her work as " "disgusting trash," (Broughton [1920] n. d.: 78) Char is hurt and distraught. The wise St John Delaval, who plays the role of mentor and guardian in the second part of the novel and to whom Char reads passages from her novel, patiently and tactfully comments, but is clearly disapproving. In both cases, any literary merits the debut novel may have possessed are completely ignored or unfairly evaluated.

\footnotetext{
${ }^{5}$ In Act III, Scene ii, when Ophelia asks, “What means this, my lord?" Hamlet replies, “"Marry, this is miching mallecho: it means Mischief"' (Shakespeare [1599?] 1993: 814).
} 


\section{Tragic Conclusions: On Fragments, Bonfires and the Death of Ambition}

Despite initial adverse criticism and her constant dread of it during her life, Broughton persisted in her writing career which spanned more than five decades ${ }^{6}$ However, she chose a different fate for her two well-meaning if naïve heroines: they are tragically destined to silence and stasis, forced by circumstances and the people closest to them to abandon writing and to choose marriage over profession - a choice that, in their case, does not bring them happiness. Disproportionate punishments are reserved for the heroines for transgressing prescribed norms and attempting to succeed in the public sphere.

\section{"Reader, I Married Another": Disillusionment, Failure and Stasis in A Fool in her Folly}

Char Hankey is the epitome of failure, for, at the end, "[t]he illusions about both her "elevating influence' and the purity of her love are destroyed" (Silberg 1977: 162): she fails to reform and eventually marry Drinkwater and, although she manages to finish the second draft of Love, her "tale of riotous yet ultimately ennobling passion" (Broughton [1920] n.d.: 312), she never publishes it, for, as she writes, "my work was accomplished, my great mission fulfilled, and [...] this noble feat had been performed not by Fulke and Eleonora, but by Bill and Char!" (313). Victorious in her writing, she is sure she would be so too in her relationship with Drinkwater. Her happiness is, however, very short-lived: Char is presented with evidence of her lover's deception - a compromising letter written by Drinkwater to her aunt Florinda. Char learns of Drinkwater's long-standing love for Florinda and of Char's own role as pawn in his schemes. Humiliated and devastated, Char acknowledges that she has been "the victim of an unprincipled blackguard" (331) and that all her convictions had been mere illusions. When this painful truth sinks in, her sense of failure is absolute her novel about triumphant love is now only a "mocking demon" (351). As expiation, after writing a letter to her mother in which she promises unconditional submission, she starts tearing the bulky manuscript, reading parts of it in the process, especially from the last chapter which she had "penned in the drunkenness of my brief and illusory triumph. By the time I had reached the word 'Finis' I had drunk the chalice of shame and mortification to the dregs" (343). Eventually, she throws "the fragments of all that remained of the fabric of my ambition and love" (345) through an open window of the train taking her home. As Tamar Heller remarks, the destruction of the manuscript is performed to avoid what Oliphant had accused female writers of sensation fiction, including Broughton, of doing, namely, "disseminating inappropriately explicit material to girls as gullible as herself" (2009: 147) and of fostering the "disease", to use Mansel's words.

Char is spared a miserable life with Drinkwater but she is still scarred for life: her humbling experience, which she describes as a "cataclysm" (Broughton [1920] n.d.: 345), proves catastrophic: "I felt no more harrowed than a stone would have done. I was - henceforth, I always should be - a stone!" (346). Char's life is now characterised by denial, alienation and lack of feeling. At home her books:

\footnotetext{
${ }^{6}$ Broughton refrained from reading or keeping reviews of her novels although she plagued her publishers with complaints about the abuse of the press. In a letter to Macmillan, Marie Corelli comments on Broughton's "unindebtedness [sic] to the Press," "which is only a herd of sheep - one rings the bell and the rest will follow" (Wood 1993: 93).
} 
grinned at me like mocking demons; and if accident put into my hands a tale of love, I threw it down with nausea. [...] At the merest hint of anything approaching tenderness in look or voice I bucked and shied so violently [...] Thus at thirty I was still unmarried.

(Broughton [1920] n.d.: 351)

The gesture of throwing down a tale of love marks the ultimate refutation of romantic notions and myths, but, more tragically, of love.

In the summary Epilogue, Char discloses the consequences her experience: she has closed herself to love and life, disbelieving in the first and making a chore of the second. When she gets married, she emphasises the sexless nature of the union and a spouse who is the antagonist of the dashing and passionate Drinkwater. Her husband, perhaps a much older man, is in need of constant care: Char is essentially his nurse and her marriage one long exercise of duty. She declares that when he proposed to her, he might have "thanked God that there was not the slightest mixture of carnal love in his feeling for her" (352). The tone and directness of this statement are powerful, with the classifying adjective "carnal" stressing Char's revulsion from sexual intimacy. Char's last confession is that she is only waiting for death to release her. Unquestionably, punishment outweighs the transgression. Closure of the plot intentionally frustrates the reader's pleasure and invites both sympathy and reflection.

The resolution of A Fool in her Folly clearly underlines Broughton's disapproval of the secluded lives and overtly-protective upbringing of girls, echoing among others Braddon's and Anne Brontë's entreaties in The Doctor's Wife and The Tenant of Wildfell Hall for a better and fuller education of girls. Barbara Silberg's description of the novel as "a study of the impact of romanticism on a sheltered and inexperienced girl, just as Austen's Northanger Abbey is a study of the effects of the Gothic novel on a similar young lady" is indeed to the mark (1977: 156). Conversely, Silberg's explanation of the ending in terms of Broughton's condemnation of "the Romantic view of passion, with its irresponsibility, its egotism, its arrogance and its illusions" (163) is only partially tenable. As the short Epilogue uncovers the desolation of a marriage without love, it transpires that, incontestably, the utter exclusion of romantic love and sexual desire has not brought Char happiness either.

\section{Discoveries, Bonfires and Resolutions: Forced Endings and Sad Beginnings in A Beginner}

The dénouement of A Beginner also reserves bitter surprises and trials for the young heroine: a New Woman in the making, Emma eventually gets a conventional ending. It marks the end of her friendship with Edgar and the destruction of her literary aspirations. Both experiences are harrowing and life-changing, and Emma is pushed into important decisions and, irrevocably, towards domesticity.

Like Austen's Emma Woodhouse, Broughton's heroine needs to learn the truth and to recognise her error in judgement; however, her realisations do not resolve into self-improvement and fulfilment. Emma's first blow comes when her suspicions of Edgar's love for her are confirmed during a short visit to his house in London and she fears a proposal is looming. Edgar has been promoted to editor of the Porch and has suddenly come into wealth, so that he can now offer Emma a future. This tense scene, which includes the resolutions of both the professional and the romantic plot, vividly reproduces the emotion of one and the confusion of the other: 
She has stood before him, silent, if not carried with him on the storm of his passion - which strikes her as of a different quality from the spurious tornado which had uprooted her Odo - yet 'dumbed' by it; but now once again at this imminence of the deciding moment of her life, the same terror as before, only a hundredfold stronger, seizes her.

The question - the demand which for weeks in the depths of her own heart she has been fighting off - is actually upon his lips. It must not - must not cross them - not yet at least. She is not ready for it - oh, more unready than ever. 'Yes' and 'no' seem equally impossible, [...]. She recognises, oh yes, she allows that without thinking of it she has contracted a debt to him, but can she pay it? Not yet - not yet; he must give her time.

(Broughton [1894] 1899: 378-9)

Ironically, in a novel in which the heroine writes a book about passion, the closest the narrative comes to it is in Edgar's mumbled short confession of love, where he describes Emma as the sole planet ruling his universe. For Emma, it does not even marginally approach the intensity of the declarations of love between her two creations, Odo and Elfrida. Emma is, however, ostensibly 'saved' by a chance glance at "a slender vellum-bound volume" (380) which includes the fatal disparaging review of Miching Mallecho. Still unaware of her authorship, when she draws his attention to the article, he describes her novel as "an ephemeral trifle" and "a peculiarly futile novel"” (384), featuring "'tampering with such themes as Heredity by inept fools"" (384). Consequently, Emma and Edgar part, and the reader is left to wonder what would have happened had Emma not seen the article that eventful day. Plainly a case of male pride and prejudice and lack of sense and sensibility, their union of "teacher and taught" could have been turned into an opportunity of reciprocal mentorship and mutual support: as Emma herself muses just a fortnight before this encounter, "[s] he chasing from his path those material obstacles whose fretting influence on his spirit she has herself witnessed; he, with indulgent admiration, sustaining and strengthening her pinions for higher flights" (364).

The last scene sees the destruction of the manuscript and the two hundred and forty-five copies of Miching Mallecho, "her beloved dead" (385), in "a funeral pyre" (391). Mrs Chantry has finally convinced Emma to withdraw her novel from circulation: "a lame and impotent conclusion of her world-mending society-teaching mission" (209). The episode is dramatically rendered to highlight Emma's humiliation and misery. The manuscript is the last to be thrown by Emma herself and the act is described in terms of a sacrificial ritual:

There is only one final act of expiation to perform, and without perceptible wincing the highpriestess advances to the edge of the fire, and tosses the original MS - the beloved, the muchtreasured, the sole - into the heart of the furnace!

(Broughton [1894] 1899: 391)

Since the relationship between Emma and her novel is throughout described in terms of a parentchild relationship, the obliteration of her manuscript and books signifies the loss of an integral part of herself, her creative side. Another relationship - that of the heroine and literature, both as creator and consumer - has been ruined, and as the distraught Emma turns physically away from the bonfire, she is symbolically moving away from her literary dreams, and, like Char, from romantic love forever.

The ending of A Beginner may not seem as tragic as that of A Fool in her Folly, but it may still be described as confrontational since it leaves the reader perplexed and in great doubt as to Emma's happiness. The novel ends with a short Epilogue, directly following the burning scene: 
The Chantry neighbourhood has ceased to give Miss Jocelyn to Mr. Greville, for the excellent reason that she has given herself. They have a house in London, and a few weeks ago the editor of the Porch, who is still unmarried, dined with them; but Mrs. Greville is not very fond of literary society.

(Broughton [1894] 1899: 394)

Sadleir describes this short concluding note as "cynical" and the novel's ending as "bitter and farcical" (1944: 87). Although the conventional closure of romance is also deployed in $A$ Beginner, unlike in, for instance, Pride and Prejudice, Emma and Jane Eyre, it does not validate romantic love. The union is not based on mutual passion, but on respect, familiarity and friendship, and it evidently brings neither emotional growth nor sexual emancipation to the heroine. This closure rules out valid alternative endings, like marrying for love and pursuing the path of creative writing, two choices which are not necessarily mutually exclusive. The meaning of marriage as closing action is, therefore, determined by what it includes as well as what it excludes.

Does the extraordinary brevity of Epilogue suggest that Broughton wanted to finish off the story for want of material? In only fifty-four words Emma's fate is revealed and sealed. I think now, for, toying with closure and readers' expectations, the closing paragraph yields a disturbing message. "The reassertion of order, through the patriarchal and patronizing discourse of the critic, and through the domestication of Emma by marriage to her 'vielle pater' is confirmed" (Gilbert 2005: 138). Marriage to Greville is the only option open to disillusioned Emma: the confused and weak heroine, a potential New Woman, has to acquiesce, renounce her dreams and be domesticated. The anonymous narrating agent is here a presence: she sees things from a detached and lucid standpoint and gives readers the last act in the play of Emma's life and then the curtain falls. Although the reader is told that Emma is contentedly and comfortably married - a muted version of Char's sexless marriage - misgivings are reinforced in the narrator's reference to Emma's presumably forced discrediting of literary society. Has Emma made the right decision? Will she be truly happy? Certainly, there is a sense of waste and failure that emerges from this matter-of-fact and somewhat ironic rendering of facts. True to the usual New Woman novel, A Beginner questions whether society is ready for female emancipation. After portraying the difficulties encountered by the innovative heroine, it purposely fates the young female artist to a symbolical death: the conventional ending satisfies Emma's patriarchal relatives and friends but debars her indefinitely from artistic creativity and self-realisation and, like Char, she is destined to silence and subservience.

\section{Conclusion}

Pondering on A Beginner's resolution, Marilyn Wood asks: "Was it a stronger character, necessity, or the lack of her own Mr Greville that made the young Rhoda Broughton, unlike Emma, persevere in her chosen career despite similar problems?" (1993: 84). Manifestly, Broughton's two beginners lack the stamina, dedication and fighting spirit of their creator, and are immediately disheartened. They are also deprived of sustained encouragement and approval from family and friends, something Broughton could always rely on. Trapped and misunderstood, they both react in extreme ways and resolve the question by impulsively opting for hibernation rather than awakening and independence. They feel compelled to escape from life, repress their creativity and abandon their literary dreams, and deny their sexuality in a marriage to an older man: for Emma the only friend and alternative suitor; for Char, an unloved 
husband. Char's marriage gives the sensation of being buried alive; her life after her disenchantment is an endless round of duty, frustration and repression - a deliberate existential death. Emma's fate similarly neither celebrates her skill nor realises her hope of adult love. The question inevitably arises as to why Broughton, an independent woman and accomplished writer, destined her well-meaning, if immature, heroines to such limited and bleak futures.

Broughton may have tried to speculate on what her life would have been without her muse and her profession, or, as Sadleir (1940) hypothesises, how she would have lived had the two failed romances in her youth been successful, she had married and renounced her career. Either way, she used these hypothetical situations to reveal important truths about woman and the imposed limitations on her life choices. Although Broughton was not an active feminist and even criticised some feminist attitudes and behaviours in her novels, she frequently showcased scenarios where her fictional women's potential, considered problematic, is often mercilessly stifled and sacrificed in the name of convention. Significantly, in A Beginner and A Fool in her Folly, Broughton's last word is that orthodox paths, unlike her hard-won success story, do not always guarantee happiness and fulfilment, and that young aspiring women writers, like Emma and Char, besides a room of their own, deserve more than anything else a fair opportunity for self-expression and self-realisation.

\section{Bibliography}

"Review of A Beginner." 1894. The Athenaeum, (5 May): 574.

Ardis, Ann L. 1990. New Women, New Novels: Feminism and Early Modernism. London: Rutgers University Press.

Austen, Jane. [1813] 1992. Pride and Prejudice. London: Marshall and Cavendish.

Austen, Jane. [1815] 1993. Emma. Hertfordshire: Wordsworth.

Austen, Jane. [1817] 1993. Northanger Abbey. Hertfordshire: Wordsworth

Bennet, Enoch Arnold. 1901. "Rhoda Broughton." In Fame and Fiction: An Enquiry into Certain Popularities, 61-8. New York: E. P. Dutton.

Boardman, Kay, and Shirley Jones, eds. 2004. Popular Victorian Women Writers. Manchester: Manchester University Press.

Braddon, Mary Elizabeth. [1864] 1998. The Doctor's Wife. Edited with and introduction by Lyn Pykett, Oxford: Oxford University Press.

Bratlinger, Patrick. 1982. "What is Sensational about the 'Sensation Novel'?" NineteenthCenturyLiterature, 37.1: 1-28.

Brontë, Anne. [1848] 1996. The Tenant of Wildfell Hall. Edited and with an introduction by Stevie Davies, London: Penguin.

Brontë, Charlotte. [1847] 1985. Jane Eyre. Edited with an introduction by Q. D. Leavis, London: Penguin.

Brontë, Emily. [1847] 1985. Wuthering Heights. Edited with an introduction by David Daiches, London: Penguin. 
Broughton, Rhoda. [1867] 1993. Cometh up as a Flower. Edited with a biographical note by Fionn O'Toole, Gloucestershire: Sutton.

Broughton, Rhoda. [1867] 1967. Not Wisely but too Well. Edited with an introduction by Francis King, London: Cassell.

Broughton, Rhoda. [1870] 1899. Red as a Rose Is She. London: Macmillan.

Broughton, Rhoda. [1880] n. d. Second Thoughts. New York: John W. Lowell.

Broughton, Rhoda. [1883] 1984. Belinda. Edited with an introduction by Tamie Watters, London: Virago.

Broughton, Rhoda. [1886] 1887. Doctor Cupid. Philadephia: Lippincott.

Broughton, Rhoda. [1894] 1899. A Beginner. London: Macmillan.

Broughton, Rhoda. 1895. Scylla and Charybdis. New York: Appleton.

Broughton, Rhoda. [1897] 1899. Dear Faustina. London: Macmillan.

Broughton, Rhoda. 1900. Foes-in-Law. New York: Macmillan.

Broughton, Rhoda. 1908. Mamma. London: Macmillan.

Broughton, Rhoda. 1912. Between Two Stools. London: Stanley Paul.

Broughton, Rhoda. 1914. Concerning a Vow. London: Stanley Paul.

Broughton, Rhoda. 1917. A Thorn in the Flesh. London: Stanley Paul.

Broughton, Rhoda. [1920] n. d. A Fool in her Folly. With a Foreword by Marie Belloc Lowndes, London: Odhams Press.

Broughton, Rhoda, and Elizabeth Bisland. 1891. A Widower Indeed. New York: Appleton.

Burstyn, Joan N. [1980] 2017. Education and the Ideal of Womanhood. New York: Routledge.

Cherry, Deborah. 1993. Painting Women: Victorian Women Artists. London: Routledge.

Cunningham, Gail. 1978. The New Woman and the Victorian Novel. London: Macmillan.

Dolin, Tim. 2016. Mistress of the House: Women and Property in the Victorian Novel. London: Routledge.

Eliot, George. [1860] 1991. Mill on the Floss. Edited with an introduction by Gordon S. Haight, Oxford: Oxford University Press.

Eliot, George. [1872] 1985. Middlemarch. Edited with and introduction by W. J. Harvey, London: Penguin.

Gänzl, Karl. 2017. Victorian Vocalists. London: Routledge.

Gilbert, Pamela K. 2005. Disease, Desire and the Body in Victorian Women's Popular Novels. Cambridge: Cambridge University Press.

Heger, Lisa. 2007. "Slumming with the New Woman: Fin de Siècle Sexual Inversion, Reform Work and Sisterhood in Rhoda Broughton's Dear Faustina." Women's Writing, 14.3: 460-75.

Heilmann, Ann. 1995. "Feminist Resistance, the Artist and "A Room of One's Own' in New Woman Fiction." Women's Writing, 2.3: 291-308. https://doi.org/10.1080/0969908950020306

Heller, Tamar. 2009. "Disposing of the Body: Literary Authority, Female Desire and the Reverse Künstlerroman in Rhoda Broughton's A Fool in her Folly." In New Woman Writers, Authority and the Body, edited by Melissa Purdue and Stacey Floyd, 139-57. Newcastle upon Tyne: Cambridge Scholars Publishing.

Jones, Shirley. 2004. "LOVE: Rhoda Broughton, Writing and Re-writing Romance." In Popular Victorian Women Writers, edited by Kay Boardman and Shirley Jones, 208-36. Manchester: Manchester University Press.

Lawrence, George A. [1857] 2015. Guy Livingstone. New York: Yurita Press. 
[Mansel, Henry L.]. 1862. "Sensation Novels.” Quarterly Review, 113 (April): 481-9.

Menon, Patricia. 2003. Austen, Eliot, Charlotte Brontë and the Mentor-lover. Hampshire: Macmillan. Meredith, George. [1885] 2016. Diana of the Crossways. Wentworth Press: New South Wales.

Oliphant, Margaret. 1855. "Modern Novelists - Great and Small." Blackwood's Edinburgh Magazine, 77 (May) 554-68.

Oliphant, Margaret. 1862. "Sensation Novels.” Blackwood's Edinburgh Magazine, 91 (May) 564-84.

Oliphant, Margaret. 1867. "Novels." Blackwood's Edinburgh Magazine, 102 (September) 257-80.

Prévost, Abbé Antoine-Françoise. 2008 (1731). Manon Lescaut, trans. Angela Scholar. Edited with an introduction by Angela Scholar, Oxford: Oxford University Press.

Rousseau, Jean-Jacques. 1997 (1761). La Nouvelle Héloüse, trans. Philip Stewart and John Vaché. Hanover: University Press of New England.

Sadleir, Michael. 1926. The Times Literary Supplement, (26 August): 549.

Sadleir, Michael. 1940. "Rhoda Broughton's Secret:- Melodrama of the Breaking Heart - A Girlhood of Bitter Disillusion.” The Times Literary Supplement, (30 November): 604.

Sadleir, Michael. 1944. Things Past. London: Chiswick Press Ltd.

Shakespeare, William. [1599?] 1993. Hamlet: Prince of Denmark. In The Illustrated Stratford Shakespeare, 799-831. London: Chancellor Press.

Silberg, Barbara. 1977. "Rhoda Broughton: A Popular Victorian Novelist." (Unpublished doctoral thesis) The Pennsylvania State University.

Thompson, Nicola Diane, ed. 1999. Woman Writers and the Woman Question. Cambridge: Cambridge University Press.

Wilt, Judith. 1976. "Meredith's Diana: Freedom, Fiction, and the Female." Texas Studies in Literature and Language, vol. 18: no. 1: 42-62.

Wood, Marilyn. 1993. Rhoda Broughton: Profile of a Novelist. Stamford: Watkins.

Woolf, Virginia. 2007. "A Room of One's Own". In The Selected Works of Virginia Woolf. Hertfordshire: Wordsworth.

Wynne, Deborah. 2016. Women and Personal Property in the Victorian Novel. London: Routledge.

Yonge, Charlotte. [1853] 1998. The Heir of Redclyffe. Edited with an introduction by Catherine WellsCole, Hertfordshire: Wordsworth. 